\title{
Nopal (Opuntia ficus-indica) energetic potential cultivated in arid and semi-arid zones of Chile: an assessment
}

\author{
Potencial energético de nopal (Opuntia ficus-indica) cultivado \\ en zonas áridas y semiáridas de Chile: una evaluación \\ Ian Homer $^{1 *}$, Maria Teresa Varnero $^{1}$, Camila Bedregal $^{1}$
}

\begin{abstract}
Renewable energies have attracted considerable attention in the past few years, not only at a national level, but also on a global one. This work investigates the use of cactus pear (Opuntia ficus-indica) plantations, as the main source for the production of biogas, and their energy potential for northern Chile. Biogas is an alternative energy for the agricultural sector and is obtained by fermentation processes of different wastes produced daily. Besides the generation of biogas, it is also possible to obtain a stabilized waste, called digestate, which can be incorporated into the soil. The soil in dry and semi-dry zones of northern Chile is poor in organic matter content, which makes it difficult to grow crops. Cactus pear is easily adapted to poor soils and deficient environmental conditions. This species presents the Crassulacean acid metabolism (CAM), and is characterized by a superficial fleshy root system that facilitates the absorption of water, allowing it to adapt well to arid conditions. Another important feature of this species is its biomass production, which can reach around $30 \mathrm{Mg} \mathrm{ha}^{-1}$ with the application of good management practices. For this reason, and for its high potential to produce biogas, it is considered a good energy alternative for northern Chile. The selection of the right biodigester will depend on the use and associated costs. The estimated potential for biogas production from Opuntia plantations in northern Chile is $13,406 \mathrm{~m}^{3} \mathrm{~kg}^{-1} \mathrm{~d}^{-1}$, and can be further improved by adding other wastes produced in the area.
\end{abstract}

Keywords: alternative energy, biogas, digestate.

\section{RESUMEN}

En los últimos años las energías renovables han atraído una atención considerable, no sólo a nivel nacional, sino también internacionalmente. Este trabajo investiga el uso de plantaciones de nopal (Opuntia ficus-indica), como la fuente principal para la producción de biogás y su potencial energético para el Norte de Chile. Biogás es una energía alternativa para el sector agrícola y se obtiene por procesos de fermentación de diferentes residuos. Además de la generación de biogás, también es posible obtener un residuo estabilizado, denominado digestato que puede ser incorporado en el suelo. El suelo en zonas áridas y semiáridas del norte de Chile es pobre en contenido de materia orgánica, pero el nopal se adapta fácilmente a suelos pobres y condiciones ambientales adversas. Esta especie presenta el metabolismo ácido de las crasuláceas (CAM) y se caracteriza por un sistema de raíz carnosa superficial que facilita la absorción de agua, permitiendo que se adapte bien a condiciones áridas. Otra característica importante de esta especie es la producción de biomasa que puede alcanzar alrededor de $30 \mathrm{Mg} \mathrm{ha-1}$ con la implementación de buenas prácticas de manejo. Por esta razón y por su alto potencial para producir biogás, se considera una alternativa energética favorable para el norte de Chile. La selección del biodigestor adecuado dependerá del uso y los costos asociados. El potencial estimado para la producción de biogás de plantaciones de Opuntia en el norte de Chile es $13.406 \mathrm{~m}^{3} \mathrm{~kg}^{-1} \mathrm{~d}^{-1}$. Esto puede optimizarse mediante la adición de otros residuos que se producen en la zona.

Palabras clave: energía alternativa, biogás, digestato.

\section{Introduction}

In recent years, the use of non-conventional renewable energy has acquired great importance worldwide as a result of high prices of oil and natural gas. At the national level, there is also the need for independence from neighboring countries in regards to energy, since $97 \%$ of oil, $86 \%$ of coal, and $78 \%$ of natural gas are imported (CNE, 2016). Biomass is a feasible energy for rural areas and the

\footnotetext{
1 Engineering and Soil Department, Faculty of Agronomic Sciences, Universidad de Chile, Casilla 1004, Santiago, Chile.

* Autor para correspondencia: ihomer@uchile.cl; ihomer.uchile@gmail.com
}

Fecha de Recepción: 27 de Noviembre, 2018.

Fecha de Aceptación: 5 de Enero, 2020. 
agricultural sector, It is also better because waste management and treatment is possible, as one of the energies produced by biomass is biogas. The process of anaerobic biodegradation of most of the organic material produces a gaseous compound of high fuel value and a stabilized waste-which can be used as fertilizer (Varnero and Homer, 2007).

Currently, arid and semi-arid areas in the North of Chile have been investigated to develop energy crops that do not affect the traditional crops intended for human consumption. This development will also grant options to small farmers in these areas to be able to appropriately use their land, which is currently poor in organic matter (but with the added benefit of electricity generation and biofertilizer) (Varnero and Homer, 2007). Within this context, the prickly pear, Opuntia ficus-indica, is an ideal species since it has a high power of adaptation to any climate and soil and resistance to drought. It is of growing interest in the production of fruit or nopalitos, which possesses a high potential for the generation of biomass to biogas and bio-fertilizer production. However, García de Cortázar and Varnero (2006) indicated that the cladodes are not by themselves a good methanogenic material. The incorporation of cladodes in the anaerobic digestion of animal manure would encourage methanogenic fermentation, provided that the $\mathrm{pH}$ of mixtures of these raw materials in ranges neutral or slightly acidic. The inclusion of an appropriate percentage of cladodes in animal manure positively influences the start time of the vegetable fermentation process (Varnero and Homer, 2007), that is attributed to the energy and carbonated source, which provides the cactus pear, favoring the development of acidogenic bacteria, which generate the substrate that requires the methanogenic bacteria (accelerating the process methanogenic and concentrating this activity in less time (Varnero, 2011).

This work seeks to promote the cactus pear plantations as an alternative energy source for farmers in marginal, or arid and semi-arid areas, mainly along with estimating the potential generation of biogas in the North of Chile.

\section{Ecological distribution of plant}

The distribution of this plant depends on factors such as the latitude and altitude, but especially important in those places where the temperatures are quite low during the winter months. It develops to $40^{\circ}$ of latitude in the northern hemisphere and, in Chile, is grown between $30^{\circ}-35^{\circ}$ of South latitude (Iglesias y Taha, 2010). The Opuntia ficus-indica, in Chile, gives two crops per year without technical intervention: the first in February-April, the second in July-September. The second crop produces just one-third the volume of the first 15-23 to 5-10 tons per ha, but it reaches higher prices (Saenz et al., 2006; Ochoa and Barbera, 2017). Developing in localities that have an annual rainfall of 80 to 800 $\mathrm{mm}$, being the region with most hectares planted, the Metropolitan Region of Chile ( $32^{\circ} 55^{\prime}$ to $34^{\circ} 19^{\prime}$ of South latitude)), which has an annual rainfall of $300 \mathrm{~mm}$. If that precipitation is lower, it will create problems in its development due to the lack of water (Franck, 2006).

It can be planted in different types of soil, from sandy and light-textured soils to clay and stony soils. However, it is recommended for softly and stony soils. In calcaric soils, they have not developed well since it reduces their growth, but in sandy soils, they thrive, due to significant drainage afforded by this type of soil (which would not allow it to face a situation of prolonged drought). In clay and silts soils or very compacted, they also have problems developing when the soil cracks or holds too much moisture, and also with high salinity (Inglese et al., 2017). It prefers soils that have depths between 20 to $40 \mathrm{~cm}$ with good drainage and permeability. Moisture must be moderate since it does not tolerate constant humidity in soils or surface groundwater. Soils with excessive potassium can result in damage to the fruit and develop scaly layers on pallets and fruit (Sudzuki et al., 1993). The pH of the soil can be neutral to slightly alkaline, ranging between 5.0 to 8.0, and organic matter levels can be deficient $(<0.5)$ (Inglese et al., 2017).

The right climate is temperate warm with maximum temperatures that fluctuate between $20^{\circ} \mathrm{C}$ at daylight and $15^{\circ} \mathrm{C}$ nocturnal to enable the Crassulacean acid metabolism CAM of the plant to reach maximum photosynthetic productivity (Nobel, 2002), and relative humidity between 60 to $80 \%$. New plantations are very sensitive to frost. Additionally, on sites where there are prevailing constant winds of moderate-intensity it is wrong to plant cactus pear, since the lifting of dust inhibits the development of the species. High-intensity winds are limiting since the cactus pear has a 
very shallow root system. This system makes them more unstable for these types of winds and prone to being knocked down. Moreover, saline, from the coastal winds, is harmful to the development of the cactus pear, independent of the intensity of the winds (Bedregal, 2010).

It can be grown from sea level up to $2,500 \mathrm{~m}$, with higher productivity between 800 and $2000 \mathrm{~m}$ of height (MINAG, 2009). In Chile, it is cultivated in the Highlands, and to the interior of Copiapó, reaching heights between 2000 to 3000 m.a.s.l. Its natural distribution is on hillsides, valleys, and flat terrain, where the incidence of light is important for the development of this plant. Therefore, care should be used in places that give shade to the cactus pear since this decreases productivity (Potgieter and DÀquino. 2017).

\section{Characterization of arid and semi-arid zones of Chile}

\section{Characterization of the soils of the North of Chile}

In Chile, the soil is a resource that is quite deteriorated mainly due to misuse. About $78 \%$ of productive soils in Chile have some degree of erosion and are facing (Ruiz, 2006) desertification processes. Thick soil textures with gravel characterize the North, considerable accumulation of salts, an arid and semi-arid climate, and covers $40 \%$ of the surface of the mainland of Chile.

The valleys in the North (Copiapó, Huasco, Elqui, Limarí, and Choapa) manifest very heterogeneous soils concerning texture, depth, stratification, complex earrings, and not extended areas soil series; causing abundant variability in their physical, chemical, and biological properties (Casanova et al., 2013). Mainly they are soils of sandy texture, with limitations of compaction, salinity, and sodicity (Doussolin and Quezada, 2008). One of the main problems for soils in the North is the accumulation of salts which derive other types of problems such as low permeability and low infiltration rate. There are saline, sodic and saline-sodic soils. The first types are those with concentrated salts higher than $0.15 \%$, with $\mathrm{pH}$ below 8.5 , making it impossible for normal plant life (since excess salts in the tissues of plants can cause injuries on them). The second type has more than $15 \%$ exchangeable sodium, $\mathrm{pH}$ higher than 8.5 , reducing permeability, and the movement of water. These levels can cause problems in the environment and agriculture due to the adverse effects on soil structural stability and electrical conductivity. It can also cause damage to the physico-chemical properties of the soil, reducing infiltration, and the hydraulic conditions, of the soil. Finally, the third type is those with a combination of both characteristics. For these three types of soils, it is necessary to develop drainage to maintain favorable conditions of moisture on the growth of the crops (Doussolin and Quezada, 2008), as well as for the incorporation of organic matter (since these types of soil are scarce).

One of the advantages of these types of soils for plantations of the cactus pear is that it is very well suited to extreme conditions. Additional advantages of the cactus pear are that the proposed usage soils do not compete with other crops, do not need a great amount of water for irrigation, and with the application of appropriate water management practices, soil and planting, come decreased risks for the sustainability of irrigated agriculture. Additionally, it can be grown without limitations in fine, loam, and coarse textures, so it is possible to be grown in the North. In the case of the rocky terrain, the cactus pear resists stony ( $<15 \%$ stones) to extremely stony ( $>60 \%$ stones). It is positive to cultivate in places without a water table, but there is constrain with a water table between $110 \mathrm{~cm}$ and $50 \mathrm{~cm}$. The last advantage is that it can be planted in areas with up to a $20 \%$ slope (CIREN, 1989).

The disadvantages of these types of soils for plantations of cactus pear is that there are low levels of nutrients and organic matter present. Also, precarious amounts of rain during the year and the geological origin have caused problems of salinity, sodicity, and other elements. For example, in the case of the boron, too much may be toxic. Salinity is a critical factor for the tuna because of its low tolerance, which also reduces the productivity and yield of crops with highly acidic $\mathrm{pH}$ (5.0) or very basic $\mathrm{pH}$ (9.8). These may cause problems with the availability of nutrients in the soil. However, all of these disadvantages can be reversed through good agricultural practices (MINAG, 2009).

Good soil management is achieved through proper preparation, which allows for the improvement of the permeability of the soil, breaking surface 
crusting, and improving water infiltration. Activities such as subsoiling, deep plowing, profile modifications, and removal of soil salts are recommended. The first two should be carried out with caution, since a mistake can cause the opposite effect; for example, reducing the water supply. At sodic soils should be avoided these activities with moist soil and heavy machinery. In saline soils, deep tillage is recommended since it improves the physical condition of permeable layers, increases water retention, and helps the salinization control when using water irrigation saline. A second activity is the contribution of organic matter to the soil, which improves the permeability of the soil, releasing $\mathrm{CO}_{2}$ and other acids during their decomposition, allowing a decrease in the $\mathrm{pH}$ of the soil. Nutrients through natural or artificial fertilizers, which improve the structure of the soil, the biological activity of the soil, and the moisture retention, can be incorporated to increase the crop yield. Sodic soils apply amendments that cause the exchange between calcium and sodium cation. The type of the amendment will depend on the specific problem of the soil. An example of amendment is the gypsum, which is mainly in clayey soils, improving the permeability of the soil (Quezada, 2008).

Regarding the supply to use in these types of soils, it is recommended to increase the amount of irrigation water for saline soils since it decreases the concentration of salts when applied more frequently and in smaller doses, but it must be remarked that clay soils require more water than sandy textures. When it rains, it is best to water to remove the salts accumulated in the roots, and thus keep the concentration of salts. Drip irrigation allows water with many salts to be used, but it is necessary to perform this wash periodically. So the salts present in the depth of the soil do not rise to the surface it is recommended to perform an antievaporative mattress on the surface to achieve proper growth of roots and to improve the hydraulic conditions of the soil. Subsurface drains increase the flow through the soil allowing the removal of a high amount of salts at greater depths. For thick soil textures, fine material is added in order to increase the storage of water in the long run (Quezada, 2008).

\section{Agro-climatic description of the North of Chile}

Several climatic types are present in the Northern zone of Chile: Desert with marine influence, inland desert, highland desert, all three with Xeric water regime (dry season extend over twelve months); arid and hyper-arid highland Steppe; arid and hyper-arid Steppe with marine influence; xeric, arid and hyper-arid inland Steppe; semi-arid warm temperate; polar and tundra in the upper Andes mountains. Each agro-climatic district is identified by a name related to its geography cities, villages, or any other geographic entity. The territory of the Atacama and Coquimbo regions is divided into 23 different agro-climatic districts (Santibañez et al., 2017).

Agro-climatic areas in Chile are critical for the production of farming systems since these are analyzed through the climate requirement of crops, agronomic, and background of the climate of the study area. At the Atacama and Coquimbo regions, there are three sectors: the coastal sector, transversal valleys, and the Andean sector. The first is characterized by a homogeneous climate between winter and summer, with winter temperatures much more benign than the other two sectors that is mainly caused by the presence of the sea, which generates bigger thermal stability. This sector $t$ is free of frost, with very little rainfall. The sector of transversal valleys presents temperatures that increase more inside de valley (coast to Andes), generating a better water shortage due to the stress of thermal oscillation between day and night. Finally, the Andean sector presents a climate that is dominated by elevations, which present more precipitation and bigger thermal oscillation than the other sectors (Santibañez et al., 2017).

The growth of cactus pear requires an optimal temperature range between $22-30{ }^{\circ} \mathrm{C}$, with a minimum temperature of $10^{\circ} \mathrm{C}$, damage by frost is produced at $-2{ }^{\circ} \mathrm{C}$ to (which is classified as moderately frost-resistant)but does not require hours of cold for growth $\left(<7^{\circ} \mathrm{C}\right)$ (CIREN, 1989). It is possible to deduce that the vast majority of the present agroclimates comply with the agro-climatic characteristics required by the cactus pear, that excludes the agroclimate central mountain range since it has very extreme temperatures in the winter, which would cause damage to plantations.

Morales et al. (2006) confirmed this information through a study conducted at the Region of Coquimbo, which indicated that the highest temperatures are in the valleys and the lowest in the cordillera. The study also indicated that the average precipitations are in valleys, the 
significat amount of precipitation is in the SouthEast area of the region, and the area with the least amount of precipitation is in the northern part of the region. Solar radiation increases from West to East, with low and flat areas that were manifesting less solar radiation.

An interesting highlight point, according to studies by Nobel (2002), is that the maximum rate of assimilation of $\mathrm{CO}_{2}$ is achieved when there is an average temperature of $25^{\circ} \mathrm{C}$ during the day and $15{ }^{\circ} \mathrm{C}$ overnight. With increases in the temperature during day and night, the rate of assimilation of $\mathrm{CO}_{2}$ decreases, with reductions up to $70 \%$ in photosynthetic activity when the temperature is $>30^{\circ} \mathrm{C}$ (Inglese et al., 2017). Based on high night temperatures, the opening of stomata plummets increasing the respiration causing more transpiration from the plant, for that reason, it is advisable that plantations, especially those with commercial feasibility, are planted in places that have hot days and cold nights.

Drought conditions develop from fleshy side roots of the taproot, which allows taking water at surface levels. However, with favorable conditions of soil and cultural management, an extended root develops penetrating deeply into the soil, reaching $80 \mathrm{~cm}$ (Prat and Franck, 2017).

According to Prat and Franck (2017), the roots have three ways to contribute to drought tolerance: first, by restricting the radical surface and reducing its permeability to water. Second, by quickly absorb small quantities of water provided by light rains. Third, decreased perspiration product to the high negative potential root.

\section{Planting systems}

In Chile, the prickly pear was planted in a system known as "locker", where four pallets are planted per position, in the corners of $1 \times 1 \mathrm{~m}$ "squares" separated by 4 x $4 \mathrm{~m}$ from each other. However, this is a system, which originates larger plants, difficult to harvest, with a big dark interior space in which no fruit is produced and to which the phytosanitary products access with difficulty (Franck, 2010).

Evaluations of the Center of Studies of Arid Zones of the University of Chile would indicate that a frame of the plantation of 4 meters between rows and 2 meters on the row is recommendable for a semi-intensive production, which, with a system of conduction in the hedge, it would allow a fast coverage of the row, and an optimal management of the crop (Franck and Muñoz, 2014). However, keep in mind that plant in high density does not mean higher productivity, since it reaches a limit in that performance does not increase, but Chile is to plant in ridges of $80 \mathrm{~cm}$ wide with distances between $2 \mathrm{~m}$ to $3 \mathrm{~m}$ between plants and $4 \mathrm{~m}$ to $5 \mathrm{~m}$ between rows. The length and width of young cladodes, showed the lower values as plant density increased (Ruiz et al., 2008). Another system is currently used in option, also in continuous hedgerows, is planting distances between plants from $1.5 \mathrm{~m}$ to $2 \mathrm{~m}$ and $5 \mathrm{~m}$ to $7 \mathrm{~m}$ between rows (Potgieter and D’Aquino, 2017).

The orientation of the plantations should be East-West, northwest-southeast, or northeastsouthwest. This way, there is an increased uptake of light, increased photosynthesis in the palettes of cactus pear, and faster rooting. In Chile, planting occurs from the mid- or the end of November until the first week of March (or once cut blades achieve its semi-dehydration) (Sudzuki et al., 1993). For the plantation of cactus pear, it is necessary to perform a pit filled with 1-2 $\mathrm{kg}$ of manure to be able to bury $2 / 3$ of the palette, with not put soil against the palette, since it can lead to rot. In soils of organic matter, it is necessary to add it in advance. Once the cactus pear has been planted, if the soil is wet is not necessary to irrigate it, not when it is dry, since it must be watered (without watering the palette directly). Also, four abundant irrigation must be carried out to ensure the rooting.

\section{Potential of biogas production}

The productivity of the plantations of cactus pear is very similar to other crops like wheat and corn since the cactus pear grows all year long. Studies have shown that 1 ha of Opuntia over 5 years old can produce up to $100 \mathrm{t}$ of fresh cladodes per year in areas with little rainfall $(\leq 300 \mathrm{~mm})$ (Nobel, 2002). As the years pass, the growth of blades decreases since the rate of net photosynthesis decreases by shading of vanes (Potgieter and DÀquino. 2017). It has no relation to the content of dry matter, which is increased every year during the year (Table 1). Pruning can yield approximately $10 \mathrm{t}$ of dry matter (DM) ha-1 year ${ }^{-1}$, and the pruning can be used for biogas, compost, or animal feed (Varnero and Homer, 
Table 1. Annual production of biomass of commercial tuna in Til Til.

\begin{tabular}{cccc}
\hline \multirow{2}{*}{ Average age of the plants (years) } & \multicolumn{3}{c}{ Dry biomass production (Ton. of M.S. ha hear $^{-1}$ ) } \\
\cline { 2 - 4 } & Pallets & Fruits & Total \\
\hline 1.5 & 5.33 & 0.10 & 5.43 \\
3.5 & 7.43 & 0.43 & 7.86 \\
5.5 & 10.50 & 3.15 & 13.65 \\
\hline
\end{tabular}

Acevedo and Doussolin, 1984.

2017). Pruning can also provide the raw material to feed digesters, combined with animal manure. Mature cladodes (1 year old) can be cut, chopped, and fed directly into the digesters. It is important to use them as soon as they have been chopped, in order to reduce biodegradation and improve the efficiency of biogas and biofertilizer production. If the capacity of the digester is not sufficient for immediate use, the cladodes can be stored in a shaded, cool, dry place for several days (Varnero and Garcia de Cortazar, 2013). In Chile, the maximum business performance is estimated at $16 \mathrm{t}$ per hectare of fruit in fresh weight for plants. The distribution of 16 to 20 years old with good management, then begins to decline between 21 to 35 years of age, producing $8 \mathrm{tha}^{-1}$.

\section{Potential production of biogas for plantations aimed at agro-industry}

Generally, in many countries, the production of cactus pear is destined for the production of fruit, either for the domestic market or for export when coupled with good management practices. For that reason, it is held as a favorable production scenario when compared to the following scenario of bioenergy crops. This scenario consists of showing the best conditions that are to face concerning management and to the conditions of the site to obtain good production plantations of cactus pear. For this, it is necessary to consider characteristics as texture clay loam, sandy clay, and sandy soil thin. Regarding $\mathrm{pH}$, this must be within the range of 7 to 8.9 with good drainage, groundwater, and the percentage of stones is less than $15 \%$ to $30 \%$ (CIREN, 1989). To keep slightly moist soil, the irrigation should be drip, ideally with 5 to 6 waterings per season, (Sudzuki et al., 1993). (Sudzuki et al., 1993).

In Chile, the totality of all of the plantations aimed at the cultivation of cactus pear (INE, 2007) reached 1,231.77 hectares, of which the Region of Atacama includes only 3.1 hectares and the Coquimbo Region contains 90450 ha (Table 2). It is estimated that all fruit production is destined for the domestic market in both regions.

Waste caused by commercial plantations were estimated to be 30 tons per hectare produced (Franck, 2006), and may have even been higher according to the plantation system and the conditions of the site. For this case, production destined for the agroindustry has been calculated the potential of biogas for optimal handling and irrigation conditions, since it is expected that this production will generate a substantial amount of fruits and residues; therefore the Region of

Table 2. Distribution of plantations of tuna in the North of Chile.

\begin{tabular}{lllc}
\hline Region & Province & Commune & Planted area (Ha) \\
\hline \multirow{2}{*}{ Atacama } & Huasco & Vallenar & 0.90 \\
Coquimbo & Elqui & La Serena & 376.7 \\
& Elqui & Vicuña & 26.9 \\
& Choapa & Canela & 0.90 \\
& Limari & Ovalle & 19.5 \\
& Limari & Combarbalá & 12 \\
& Limari & Monte Patria & 3.4 \\
& Limari & Punitaqui & 10.9 \\
\hline
\end{tabular}


Atacama and Coquimbo would produce 93 and 13,509 tons, respectively. The results of 13,602 tons generated by waste per year for North Chico in Chile, equivalent to 37.27 tons per day, which can be used as raw material for biogas generation. Furthermore, Contreras and Toha (1984) studies indicated that three $\mathrm{kg}$ of dried cactus pear are capable of producing $1 \mathrm{~m}^{3}$ of biogas at the same time, implying a production of $10 \mathrm{~kW}-\mathrm{h}$. Then, with 30 tons can reach occur $18 \mathrm{~m}^{3}$, equivalent to $150 \mathrm{~kW}$-h (Franck, 2006).

Varnero and Homer (2017) indicated that the calorific value of the cactus pear was 7,058 Kcal $\mathrm{m}^{-3}$, with a range of error ranging from 6,800 to $7,200 \mathrm{Kcal} \mathrm{m}^{-3}$. Also, he pointed out that the potential of biogas for Opuntiaficus-indica can be expressed as $0.360 \mathrm{~m}^{3} \mathrm{~kg}^{-1}$ dry matter. Therefore, the estimate of the full potential of biogas for the North of Chile is $37,240 * 0.360=13,406.4 \mathrm{~m}^{3}$ day $^{-1}$ of biogas.

This biogas potential would make it possible to meet the basic needs of 3,713 families in rural areas based on $3.61 \mathrm{~m}^{3}$ biogas day ${ }^{-1}$ of Opuntia ficus-indica (Table 3) (using an average family of 5 people).

\section{Potential production of biogas for plantations aimed exclusively at the production of biogas}

In this case, the estimation of biogas must be checked for two scenarios (under normal conditions and in substandard conditions), because it is assumed that there is a concern in commercial plantations.

\section{Setting for sites with regular conditions}

Textured soils are considered silty clay loam, clay loam, silty loam, and sandy loam, whose $\mathrm{pH}$ is 6 , and the percentage of stones is between $35-60 \%$.
The phreatic level is $110 \mathrm{~cm}$, and the degree of inclination of the slope varies between 6 to $10 \%$. Irrigation is 2-3 times in total during December, January, and February (Sudzuki et al., 1993). In this case, it has been estimated that the production of waste by the plantations is 18 ton $\mathrm{ha}^{-1}$ per year, to observe the difference in production according to the granted management and site features. The Atacama Region produced 55.8 ton ha ${ }^{-1}$ year-1 and the Region of Coquimbo would produce a total of $8,105.4$ ton $\mathrm{ha}^{-1}$ per year, giving a total of production for Norte Chico 8,161,2 ton ha ${ }^{-1}$ year $^{-1}$ (which is equivalent to 22,36 ton ha ${ }^{-1}$ daily, exclusively aimed at the generation of biogas). The estimation of the potential of biogas for the North of Chile, according to this regular scenario, would be $22,360 * 0.360=8,049.6 \mathrm{~m}^{3} \mathrm{day}^{-1}$ of biogas. This value indicates that the basic needs of 2,229 families could be met using this scenario.

\section{Setting for sites with poor conditions}

Refer to soils with clay texture, with phreatic at $50 \mathrm{~cm}$, extremely stony ( $>60 \%$ of stones), $\mathrm{pH} 5$, and irrigation by sporadic Groove (CIREN, 1989). For this condition, Acevedo and Doussoulin (1984), indicated that a plantation of cactus pear can produce approximately 13.65 tons of dry matter per year (Cactus pear from 5 years of age); therefore, the potential of biogas production from plantations is estimated to be 10 ton ha ${ }^{-1}$ annual. Consequently, the Atacama Region has 3.1 hectares for the production of cactus pear and the Coquimbo Region presents 450.3 hectares. Accordingly each would produce 31 and 4,503 tons per year, respectively. This would result in 4,534 tons per year (or the equivalent to 12.42 tons/day) produced by Norte Chico of Chile for the production of biogas. The estimation of the potential of biogas for the North of Chile would be

Table 3. A family of 5 people average consumption.

\begin{tabular}{|c|c|c|}
\hline & $\begin{array}{l}\text { Average biogas consumption } \\
\text { Calorific value } \\
5,000 \mathrm{kcal} \mathrm{m}^{-3}\end{array}$ & $\begin{array}{c}\text { Nopal biogas consumption } \\
\text { Calorific value } \\
7,058 \mathrm{kcal} \mathrm{m}^{-3}\left(75 \% \text { of } \mathrm{CH}_{4}\right)\end{array}$ \\
\hline Kitchen (5 hours) & $0.30 \mathrm{~m}^{3} \mathrm{~h}^{-1} \times 5 \mathrm{~h}=1.50 \mathrm{~m}^{3}$ day $^{-1}$ & $0.21 \mathrm{~m}^{3} \mathrm{~h}^{-1} \times 5 \mathrm{~h}=1.05 \mathrm{~m}^{3} \mathrm{day}^{-1}$ \\
\hline 3Lamps (3 hours) & $0.15 \mathrm{~m}^{3} \mathrm{~h}^{-1} \times 3 \mathrm{~h} \times 3=1.35 \mathrm{~m}^{3} \mathrm{day}^{-1}$ & $0.11 \mathrm{~m}^{3} \mathrm{~h}^{-1} \times 3 \mathrm{~h} \times 3=0.99 \mathrm{~m}^{3} \mathrm{day}^{-1}$ \\
\hline Cooling médium & $2.20 \mathrm{~m}^{3} \mathrm{~h}^{-1}$ x $1=2.20 \mathrm{~m}^{3}$ day $^{-1}$ & $1.57 \mathrm{~m}^{3} \mathrm{~h}^{-1} \mathrm{x} 1=1.57 \mathrm{~m}^{3}$ day $^{-1}$ \\
\hline Total & $5.05 \mathrm{~m}^{3}$ day $^{-1}$ & $3.61 \mathrm{~m}^{3} \mathrm{day}^{-1}$ \\
\hline
\end{tabular}

Source: Varnero, 2010; Varnero and Homer, 2017. 
$12,420 * 0,360=4,471.2 \mathrm{~m}^{3}$ day $^{-1}$ of biogas, which would feed 1,238 families made up of 5 people.

\section{Conclusions}

It can be concluded that Opuntia ficus-indica is a species that can be easily adapted to different types of terrains and climates present in arid and semi-arid zones of Chile. Also, due to features presenting its CAM metabolism, the cactus pear can grow in arid and semi-arid regions anywhere in the world, as well as in places where the soils are much deteriorated (For example, land eroded or abandoned in the North of Chile). To the properly utilize of the cactus pear, agricultural practices must involve methods to improve its Physico-chemical composition, proper drainage, and proper irrigation are applied.

Currently, crops of cactus pear are not only suitable for the production of fruits, jams, vegetables, but it is also possible for the cactus pear to be utilized in the production of clean, renewable energy through the methanogenic fermentation of the cladodes. The generation of biogas, using exclusively cladodes, has limitations for the values of acidic $\mathrm{pH}$ observed in anaerobic digestion, especially when they are young cladodes. This problem can be neutralized by mixing the cladodes, with plant debris or animals, in mixture proportions that reach ranges of $\mathrm{pH}$ close to neutrality. The digestate is another product of interest when obtained from the fermentation, and when be stabilized and sanitized, the organic material, can be applied to the soil (improving physical, chemical, and biological properties). That benefits the plantations of cactus pear, by giving them a higher performance, which varies between 10 ton $\mathrm{ha}^{-1}$ to 30 ton ha ${ }^{-1}$ approximately (depending on conditions of the site, climate, cultural management and the availability of economic resources).

High biomass yields are obtained in commercial plantations of cactus pear for the agro-industry. Therefore, it constitutes the most favorable scenario for potential biogas production, with estimated values of approximately $13,406.4 \mathrm{~m}^{3}$ biogas per day $^{-1}$. On the other hand, when selecting sites with moderate to severe limitations, and taking into account plantations of cactus pear generated only for energy purposes, the scenarios for potential biogas production decreases, with estimated values ranging from $8,049.6$ to $4,471.2 \mathrm{~m}^{3}$ per day ${ }^{-1}$, respectively. This production can be a useful alternative for many families in the rural sector of the arid and semi-arid zones of Chile.

\section{Literature Cited}

Casanova, M.; Salazar, O.; Seguel, O.; Luzio, W. 2013. The soils of Chile. World Soils Book Series. Hartemink, A. (Ed.). Springer. Madison, USA. 185 p.

CIREN.

1989. Frutales menores y de hoja persistente, CIREN 84. Requerimiento de clima y suelo Centro de información de recursos naturales. Centro de información de recursos naturales. Santiago, Chile.63 p.

Contreras, S.; Toha, J.

1984. Biogas production form a suspension of homogenized cladodes of the cactus Opuntia cacti. Ferment. Technol, 62(2): 601-605.

CNE.

2016. BNE 2016- balance energía global. Comisión Nacional de Energia. Available athttp://www.censoagropecuario.cl/ noticias/08/6/10062008.html: http://datos.energiaabierta. cl/dataviews/244115/bne-2016-balance-energia-globaltcal/. Consulted: 27/sep/2018.

Doussoulin, EE.; Quezada, C.L.

2008. Introducción al problema de los suelos de las zonas áridas de Chile. En Quezada C.; Sandoval M.; Zagal E. (Eds.) Manejo de Suelos en Zonas Áridas. Chile. pp. 22-30. Franck, N.

2006. Alternativas para la producción de bioenergía en las zonas áridas y semiáridas de Chile. In: Acevedo, E. (Ed). Agroenergía, un desafío para Chile. Serie Ciencias Agronómicas No 11. Universidad de Chile, Santiago, Chile. pp. 137-148.

Franck, N.

2010. Perspectivas de la tecnificación del cultivo de la tuna. Informativo $\mathrm{N}^{\circ}$ 21. INIA-Ururi. Arica, Chile. 4 p.

Franck, N.; Muñoz-Aravena, V.

2014. Frutales para zonas áridas y semiáridas. Serie ciencias agronómicas $\mathrm{N}^{\circ} 20$. Ediciones Antumapu. Santiago, Chile. $233 \mathrm{p}$.

García de Cortázar, V.; Varnero, M.T.

2006. Producción de bioenergía y fertilizantes a partir de los nopales. In: Saenz, C. (ed.). Utilización agroindustrial del nopal. Boletín de servicios agrícolas de la FAO 162. Roma, Italia. pp. 113-119.

Iglesias, R.; Taha, E.

2010. Monografías de especies anuales, arbustivas y acuícolas con potencial energético en Chile. Oficina de Estudios y Políticas Agrarias (ODEPA). Chile. 42 p.

Instituto Nacional de Estadística (INE), Chile.

2007. Censo Agropecuario y Forestal. Santiago, Chile. Available at:http://www.ine.cl/estadisticas/censos/censoagropecuario-y-forestal-2007. Consulted: 18/Nov/2016. Inglese, P.; Liguori, G.; de la Barrera, E.

2017. Ecophysiology and reproductive biology of cultivated cacti. In: Inglese, P.; Mondeagon, C.; Nefzaoui, A.; Sáenz, 
C. (eds.). Crop ecology, cultivation and uses of cactus pear. FAO and ICARDA. Rome, Italy. p. 29-42.

López, C.

1995. El cultivo de la tuna. El Campesino, CXXVI (12): 14-23.

MINAG.

2009. El cultivo de la tuna, Opuntia ficus índica. Gerencia Regional Agraria La Libertad, Ministerio de Agricultura. Trujillo, Perú. 18 p.

Morales, L.;Canessa, F.; Mattar, C.; Orrego, R.; Matus, F. 2006. Caracterización y zonificación edáfica y climática de la Región de Coquimbo. R.C. Suelo Nutr. Veg. 6(3): 52-74.

Nobel, P.S

2002. Cactus physiological ecology, emphasazing gas exchange of Platyopuntias fruit. Acta Hortic., 58: 143-150.

Ochoa, M.J.; Barbera, G.

2017. History and economic and agro-ecological importance. In: Inglese, P.; Mondeagon, C.; Nefzaoui, A.; Sáenz, C. (eds.). Crop ecology, cultivation and uses of cactus pear. FAO and ICARDA, Rome, Italy. pp. 1-11.

Quezada, C.

2008. Estrategia para el manejo de suelos salinos. En Quezada C.; Sandoval M.; Zagal E. (Eds.) Manejo de Suelos en Zonas Áridas. Chile .Primera edición. (vol. 3). Departamento de suelos y recursos naturales, Facultad de Agronomía, Universidad de Concepción. Concepción, Chile. pp. 22-3.

Prat, L.; Franck, N.

2017. Morrphology and anatomy of platyopuntiae. In: Inglese, P.; Mondeagon, C.; Nefzaoui, A.; Sáenz, C. (eds.). Crop ecology, cultivation and uses of cactus pear. FAO and ICARDA, Rome, Italy. pp. 21-28.

Potgieter, J.; DÀquino, S.

2017. Fruit production and post-harvestt management. In: Inglese, P.; Mondeagon, C.; Nefzaoui, A.; Sáenz, C. (eds.). Crop ecology, cultivation and uses of cactus pear. FAO and ICARDA, Rome, Italy. pp. 51-69.
Ruiz, G.

2006. El sistema de incentivos para la recuperación de suelos en la zona norte. En: Quezada C.; Sandoval M.; Zagal E. (Eds.) Manejo de Suelos en Zonas Áridas.Primera edición (vol. 3). Departamento de suelos y recursos naturales, Facultad de Agronomía, Universidad de Concepción. Concepción, Chile. pp. 5-10.

Ruiz, F.; Alvarado, J.; Murillo, B.; García, J.L.; Pargas, R.; Duarte, J.; Beltran, F.; Fenech, L.

2008. Rendimiento y crecimiento de nopalitos de cultivares de nopal (Opuntia ficus-indica) bajo diferentes densidades de plantación. Universidad Autónoma de Baja California Sur y Centro de Investigaciones Biológicas del Noroeste. La Paz, México. 35 p.

Saenz, C.; Berger, H.; Corrales Garcia, J.; Galletti, L.; Garcia de Cortazar, V.; Higuera, I. Mondragon, C.; Rodriguez Feliz, A.; Sepulveda, E.; Varnero, M.T. eds.

2006. Utilización agroindustrial del nopal. FAO Plant Production and Protection. Paper No 162. Rome, Italy 165 p.

Santibáñez, F.; Santibáñez, P.; Caroca, C.; González, P. 2017. Atlas Agroclimático de Chile. Tomo II: Regiones de Atacama y Coquimbo. 1era Ed. Santiago, Chile. 178 p.

Sudzuki, F.; Muñoz, C.; Berger, H.

1993. El cultivo de la tuna. Departamento de producción agrícola. Facultad de ciencias agrarias y forestales. Universidad de Chile. Santiago, Chile. 88 p.

Varnero, M.T.

2011. Biogas manual. FAO. Santiago, Chile. 119 p.

Varnero, M.T.; Homer, I.

2017. Biogas production. In: Inglese, P.; Mondeagon, C.; Nefzaoui, A.; Sáenz, C.(eds.). Crop ecology, cultivation and uses of cacus pear. FAO and ICARDA. Rome, Italy. pp. 187-194.

Varnero, M.T.; Garcia de Cortazar, V.

2013. Production of bioenergy and fertilizers from cactus cladodes. In: Saenz, C. (ed.). Agro-industrial utilization of cactus pear. Rural Infrastructure and Agro-Industries Division, FAO. Rome, Italy. pp. 103-109. 
